\title{
$5-2015$
}

\section{Spotlight on Economic Development Grantmaking in Ohio}

\author{
Molly Schnoke \\ Cleveland State University, m.s.schnoke@csuohio.edu
}

Follow this and additional works at: https://engagedscholarship.csuohio.edu/urban_facpub

Part of the Urban Studies and Planning Commons

How does access to this work benefit you? Let us know!

\section{Repository Citation}

Schnoke, Molly, "Spotlight on Economic Development Grantmaking in Ohio" (2015). All Maxine Goodman Levin School of Urban Affairs Publications. 01231286.

https://engagedscholarship.csuohio.edu/urban_facpub/1286

This Report is brought to you for free and open access by the Maxine Goodman Levin School of Urban Affairs at EngagedScholarship@CSU. It has been accepted for inclusion in All Maxine Goodman Levin School of Urban Affairs Publications by an authorized administrator of EngagedScholarship@CSU. For more information, please contact library.es@csuohio.edu. 


\title{
SPOTLIGHT ON ECONOMIC DEVELOPMENT GRANTMAKING IN OHIO
}

\author{
By Molly Schnoke, Cleveland State University
}

Foundation Center-Cleveland, in partnership with Cleveland State University, the Burton D. Morgan Foundation, and the George Gund Foundation, with additional support from the Unger Family Foundation, is pleased to present this report on economic development grantmaking in Ohio for the period 2002 to 2012. This ten-year spotlight examines the funding priorities of large private and community foundations that have engaged in supporting economic development in Ohio during the pre- and post-recessionary period. This report is the third in a series of briefs examining foundation grantmaking in the area of economic development. ${ }^{1}$

\section{ECONOMIC DEVELOPMENT GRANTMAKING SAMPLE AND SUMMARY}

This analysis is based on Foundation Center's FC1000 set, which includes all grants of $\$ 10,000$ or more reported by 1,000 of the largest U.S. independent, corporate, community, and grantmaking operating foundations based on total giving. For community foundations, the set includes only discretionary grants and donor-advised funds (when available). The set accounts for approximately half of giving by all of the more than 86,000 active U.S. grantmaking foundations. It does not include grants to individuals. In the 2012 set, there were 153,821 grants totaling $\$ 22.4$ billion. Of the 1,000 foundations in the sample, 157 made grants for economic development to Ohio-based recipient organizations between 2002 and 2012.

In 2012 , only 33 (or 3 percent) of foundations in the sample were located in the state of Ohio, but they provided 70 percent of the total number of grants awarded to recipients in the state for economic development. The remaining 30 percent of grants were awarded by funders from 17 other states.

The report examines giving across the state of Ohio, as well as within its major metropolitan areas: Akron, Cleveland, Canton, Cincinnati, Columbus, Dayton, Toledo, and Youngstown.

The foundation giving represented in this report does not reflect the thousands of smaller private and community foundations located in the U.S. that provide economic development grants.

Between 2002 and 2012 economic development grants were not captured evenly across the metropolitan areas of the state. The Cleveland Metropolitan Area captured a dominant share of the economic development grants made in Ohio. Together, Columbus and Cleveland capture nearly 70 percent of the economic development grants made to Ohio-based nonprofits for economic development. Nonprofits that engage in economic development activities receive a significant share of grants from community foundations. Nearly 30 percent of economic development grants in Ohio were awarded by two large community foundations, Cleveland Foundation and The Columbus Foundation.
The report shows that there was a peak in grants and dollars awarded in 2008 due in large part to a one-time $\$ 20$ million award from the John S. and James L. Knight Foundation, with a subsequent decline in 2009. The recession's impact on foundation endowments, and consequently reflected in their subsequent giving, may have also played a role in declining grants in 2009. In the most recent years, grant dollars awarded for economic development have not substantially increased from pre-recession levels.

\section{LONG-TERM TRENDS}

In 2012, Ohio recipients received a total of $\$ 406,141,396$ in support from sampled foundations, of which 9 percent was directed to economic development activities (Figure 1). During the period 2002 to 2012, foundations awarded 3,748 grants totaling $\$ 368.4$ million for economic development to organizations in the state of Ohio.

Though more grants have been awarded in the years 2010 through 2012, the total dollars awarded have fluctuated over the 11-year reporting period (Figure 2). And although the number of grants awarded in 2012 declined from 2011, it nonetheless surpassed all other prior years.

\section{FIGURE 1 Foundation Support for Ohio, 2012}

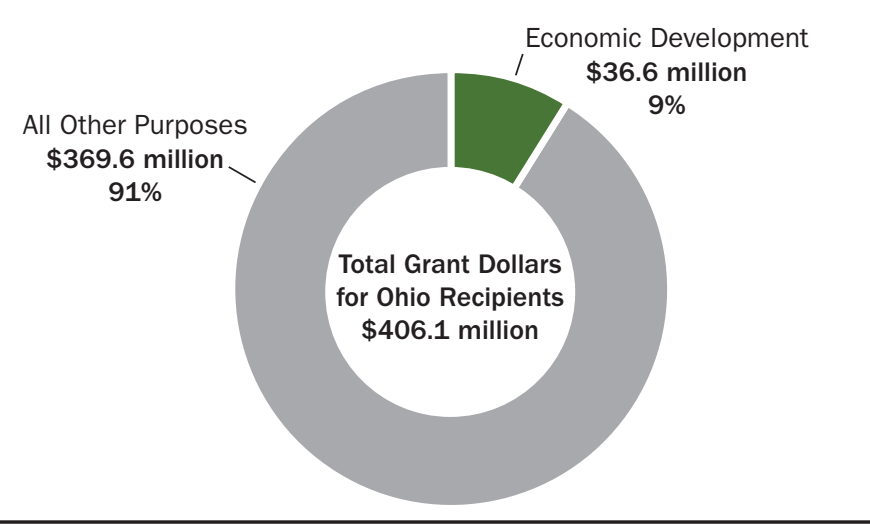

SOURCE: Foundation Center, 2015. 
Dollars awarded and number of grants follow a similar trend from 2002 through 2006. In 2007, there was a decline in the number of grants awarded, but a significant increase in the total dollars awarded for economic development in the state.

A clear uptick is seen in both number of grants and dollars awarded in 2008. The large spike observed in dollars awarded can partly be attributed to a $\$ 20$ million award from the John S. and James L. Knight Foundation to University of Akron Foundation Biolnnovation Institute to create the Knight Research and Education Collaborative (Austen Biolnnovation Institute) to manage six research, educational, and clinical initiatives expected to improve Akron's economy and quality of life by bringing in more than $\$ 125$ million dollars and creating 2,100 jobs. Even without this exceptionally large gift, 2008 would have seen an appreciable increase in economic development support in Ohio.

The Great Recession undoubtedly contributed to the reduction in foundation giving for economic development in Ohio in 2009 and 2010. However, the extent of the recession's impact on this change cannot be precisely determined. Moreover, while overall giving was lower than in the peak year of 2008 , it nonetheless remained well above levels recorded in the first half of the 2000s.

Seven foundations awarded 100 or more grants for economic development in Ohio for the period 2002 to 2012 (Table 1). Overall, these seven foundations accounted for half of the grants awarded in the state during this period. These foundations have all provided consistent long-term investment in economic development activities in the state.

\section{TABLE 1 Top Foundations Awarding Economic Development Grants by Number of Grants, 2002 to 2012}

\begin{tabular}{lccc}
\hline Foundation Name & Type $^{1}$ & No. Grants & $\%$ \\
\hline Cleveland Foundation & CM & 639 & 17.0 \\
$\begin{array}{l}\text { Columbus Foundation and } \\
\text { Affiliated Organizations }\end{array}$ & CM & 459 & 12.2 \\
George Gund Foundation & IN & 294 & 7.8 \\
PNC Foundation & CS & 146 & 3.9 \\
KeyBank Foundation & CS & 129 & 3.4 \\
Burton D. Morgan Foundation & IN & 113 & 3.0 \\
Eva L. and Joseph M. & IN & 109 & 2.9 \\
Bruening Foundation & & & \\
Subtotal & & 1,889 & 50.4 \\
Total & & 3,748 & 100.0 \\
\hline
\end{tabular}

SOURCE: Foundation Center, 2015.

${ }^{1} \mathrm{IN}=$ Independent; $\mathrm{CM}=$ Community; $\mathrm{CS}=$ Corporate.

Among the top 10 foundations awarding grants in Ohio for economic development by dollars between 2002 and 2012, all but two foundations were based in Ohio (Table 2). The secondranked John S. and James L. Knight Foundation (Florida) and 10th-ranked Ewing Marion Kauffman Foundation (Missouri) were located outside of Ohio. Some of the Knight Foundation's grants have supported organizations such as the Greater Akron Chamber, Fund for Our Economic Future, The University of Akron, JumpStart, Akron Area Arts Alliance, and University Park Alliance. The Kauffman Foundation has awarded grants to organizations

\section{FIGURE 2 Number and Dollars of Economic Development Grants Awarded to Ohio, 2002 to 2012}
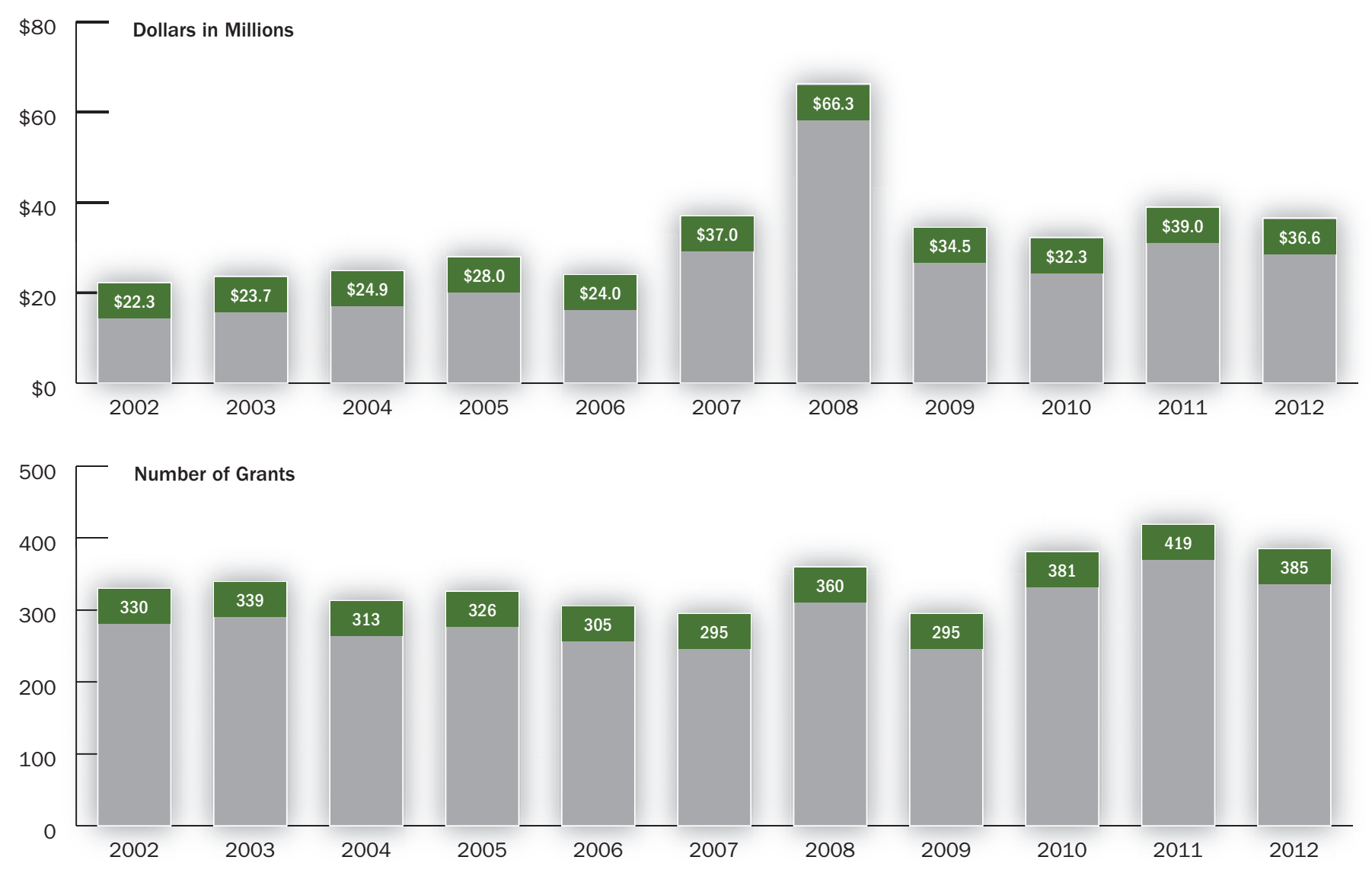

SOURCE: Foundation Center, 2015. 
such as the State Science and Technology Institute (SSTI), Enterprise Development Corporation, The College of Wooster, National Business Incubation Association, and Consortium for Entrepreneurship Education.

From 2002 through 2012, a total of 3,748 grants were awarded to Ohio-based non-profit organizations by the largest 1,000 foundations in the country. The Cleveland-Elyria-Mentor

\section{MISSION INVESTING BOLSTERS GRANTS FOR ECONOMIC DEVELOPMENT}

Increasingly, Ohio foundations are making loans, bank deposits, or equity investments to finance economic development initiatives. Such mission-related investments can significantly deepen the impact of a foundation's grants.

Two distinct categories exist: A "market-rate mission-related investment" (MRI) is funded from a foundation's assets and expected to deliver both positive social impact and market-rate returns. By comparison, a "program-related investment" (PRI) counts toward a foundation's charitable distribution requirement and typically yields a below-market-rate return. The tax code counts the entire amount of a PRI as a "qualifying distribution" in the year in which it is made, essentially the same treatment afforded grants.

Foundation Center reports over $\$ 48$ million (38 discreet transactions) in program-related investments by foundations for Ohio economic development between 2002 and 2012. Both community foundations (Barberton, Cleveland, Cincinnati and Columbus) and private foundations (Gund, MacArthur, Hubert Family and Turner) are among the PRI investors. This $\$ 48$ million is in addition to the $\$ 368$ million in grants made during the same period.

Our field has yet to compile data on foundation equity investments in regionally-focused capital funds, such as NEO Capital Fund and Early Stage Partners. We should do so soon to gain a more complete picture of philanthropic resources directed toward economic development in Ohio.

For more detail, see www.missioninvestors.org, the site of Mission Investors Exchange.

-Robert Jaquay, Associate Director The George Gund Foundation
Metropolitan Statistical Area captured by far the largest share of those grants with 1,768 (47 percent) going to organizations engaged in economic development activities in Cuyahoga, Lake, Lorain, Geauga, and Medina counties (Figure 3). The second largest share was captured by the Columbus Metropolitan Area, which netted a total of 764 grants since 2002.

The Cleveland Metropolitan Area captured the largest share of economic development grants for every year between 2002 and 2012. All of the metro areas experienced fluctuations in grants received, and five of the eight metro areas (along with the remainder of the state) displayed an uptick in the number of grants in 2008 and a subsequent decline in 2009 . Toledo was the only metro area to report an increase in number of grants received from 2008 to 2009 , going from six grants to nine grants. Overall, grants

\section{FIGURE 3 Share of Total Number of Grants Awarded for Economic Development by Metropolitan Area, 2002 to 2012}

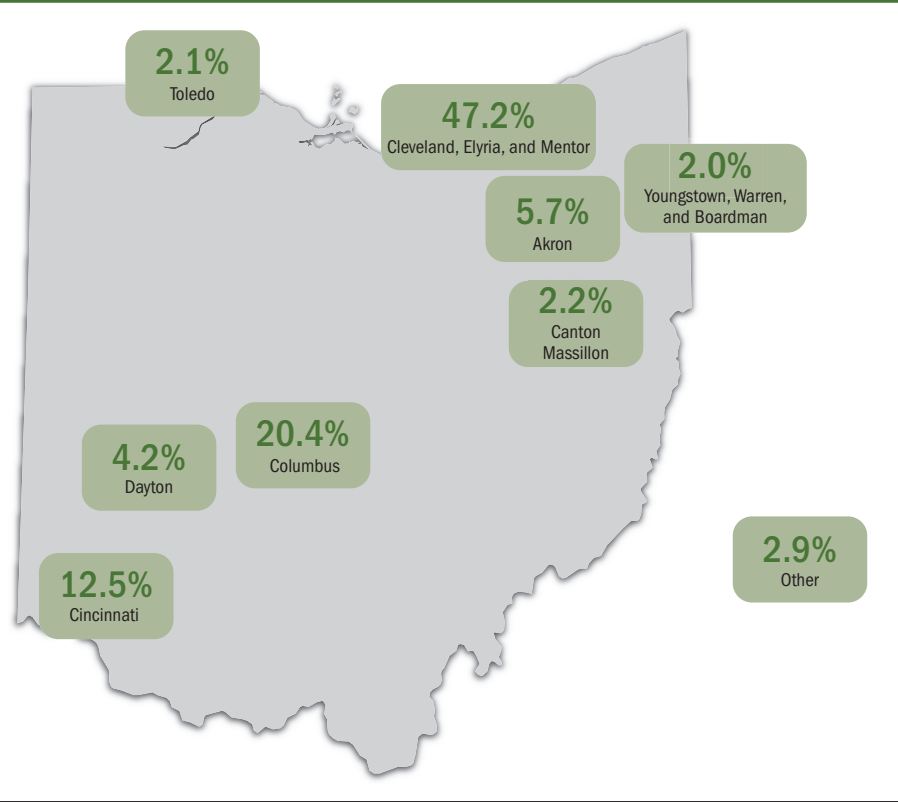

SOURCE: Foundation Center, 2015

\section{TABLE 2 Top 10 Foundations Awarding Economic Development Grants in Ohio by Dollar Amount, 2002 to 2012}

\begin{tabular}{|c|c|c|c|c|c|c|c|}
\hline & Foundation Name & State & Type $^{1}$ & Amount & $\%$ & No. Grants & $\%$ \\
\hline 1 & Cleveland Foundation & $\mathrm{OH}$ & $\mathrm{CM}$ & $\$ 81,270,450$ & 22.1 & 639 & 17.0 \\
\hline 2 & John S. and James L. Knight Foundation & $\mathrm{FL}$ & IN & $47,428,600$ & 12.9 & 36 & 1.0 \\
\hline 3 & George Gund Foundation & $\mathrm{OH}$ & IN & $31,022,127$ & 8.4 & 294 & 7.8 \\
\hline 4 & Columbus Foundation and Affiliated Organizations & $\mathrm{OH}$ & $\mathrm{CM}$ & $26,134,208$ & 7.1 & 459 & 12.2 \\
\hline 5 & Burton D. Morgan Foundation & $\mathrm{OH}$ & IN & $19,039,659$ & 5.2 & 113 & 3.0 \\
\hline 6 & Carol \& Ralph Haile, Jr./U.S. Bank Foundation & $\mathrm{OH}$ & IN & $15,769,288$ & 4.3 & 71 & 1.9 \\
\hline 7 & St. Lukes Foundation of Cleveland & $\mathrm{OH}$ & $\mathrm{CM}$ & $11,861,814$ & 3.2 & 58 & 1.5 \\
\hline 8 & Turner Foundation & $\mathrm{OH}$ & IN & $10,468,796$ & 2.8 & 36 & 1.0 \\
\hline 9 & GAR Foundation & $\mathrm{OH}$ & IN & $6,856,528$ & 1.9 & 72 & 1.9 \\
\hline \multirow[t]{3}{*}{10} & Ewing Marion Kauffman Foundation & MO & IN & $6,796,620$ & 1.8 & 51 & 1.4 \\
\hline & Top 10 Subtotal & & & $\$ 256,648,090$ & 69.7 & 1,829 & 48.8 \\
\hline & Total & & & $\$ 368,416,363$ & 100.0 & 3,748 & 100.0 \\
\hline
\end{tabular}

SOURCE: Foundation Center, 2015.

${ }^{1} \mathrm{~N}=$ Independent; $\mathrm{CM}=$ Community; $\mathrm{CS}=$ Corporate. 
to Ohio for economic development have increased 16 percent between 2002 and 2012. By 2010, the Canton, Cincinnati, Cleveland, and Columbus metropolitan areas had all recovered.

Throughout the period studied, the Cleveland Metropolitan Area has consistently captured a greater share of economic development grant dollars compared to other metropolitan areas in the state. Although the Cleveland area has consistently accounted for a larger share of grant dollars, this gap widened considerably after 2006 , particularly when the $\$ 20$ million Knight Foundation grant is excluded from the total 2008 grants awarded to the Akron Metro Area (Figures 4 and 5).

From the available data, it is unclear why such a gap exists. It may be that the economic development space in the Cleveland area was accelerating or expanding initiatives, or perhaps foundations in the region were strategically increasing their funding for economic development-related activities. Further investigation would be needed to determine the origins of this trend.

Although foundation giving in the state of Ohio for economic development increased by 64 percent overall between 2002 and 2012, there were varying levels of growth (and decline) among the major metropolitan areas (Table 3). The Cleveland Metropolitan Area saw the most significant gains of all the major metropolitan areas, with an increase in support of 158 percent. Both the Columbus and
Akron metro areas saw gains in excess of 100 percent. Other metro areas did not fare as well. For example, Toledo (down 90 percent) and Canton (down 84 percent) both witnessed declines in grant support over 2002, as did the remainder of the state, which saw a 50 percent decline in grant dollars awarded for economic development between 2002 and 2012.

TABLE 3 Change in Economic Development Grantmaking in Ohio by Metropolitan Area, 2002 to 2012

\begin{tabular}{lrrr}
\hline Metropolitan Area & $\begin{array}{c}\text { 2002 Dollar } \\
\text { Amount }\end{array}$ & $\begin{array}{c}\text { 2012 Dollar } \\
\text { Amount }\end{array}$ & $\begin{array}{r}\text { Percent } \\
\text { Change }\end{array}$ \\
\hline Akron, OH & $\$ 873,979$ & $\$ 1,940,000$ & $122 \%$ \\
Canton-Massillon, OH & $\$ 248,834$ & $\$ 40,000$ & $-84 \%$ \\
Cincinnati-Middletown, OH-KY-IN & $\$ 4,214,276$ & $\$ 3,956,510$ & $-6 \%$ \\
\hline Cleveland-Elyria-Mentor, OH & $\$ 9,487,295$ & $\$ 24,492,929$ & $158 \%$ \\
Columbus, OH & $\$ 1,860,354$ & $\$ 3,754,004$ & $101 \%$ \\
Dayton, OH & $\$ 2,005,333$ & $\$ 1,305,700$ & $-35 \%$ \\
Toledo, OH & $\$ 1,891,860$ & $\$ 197,500$ & $-90 \%$ \\
Youngstown-Warren-Boardman, OH-PA & $\$ 115,000$ & $\$ 125,000$ & $9 \%$ \\
Rest of Ohio & $\$ 1,557,253$ & $\$ 773,139$ & $-50 \%$ \\
\hline All & $\$ 22,254,184$ & $\$ 36,584,782$ & $64 \%$ \\
\hline
\end{tabular}

SOURCE: Foundation Center, 2015. Dollar amount in thousands.

FIGURE 4 Total Number of Economic Development Grants Awarded by Top Four Metropolitan Areas, 2002 to 2012

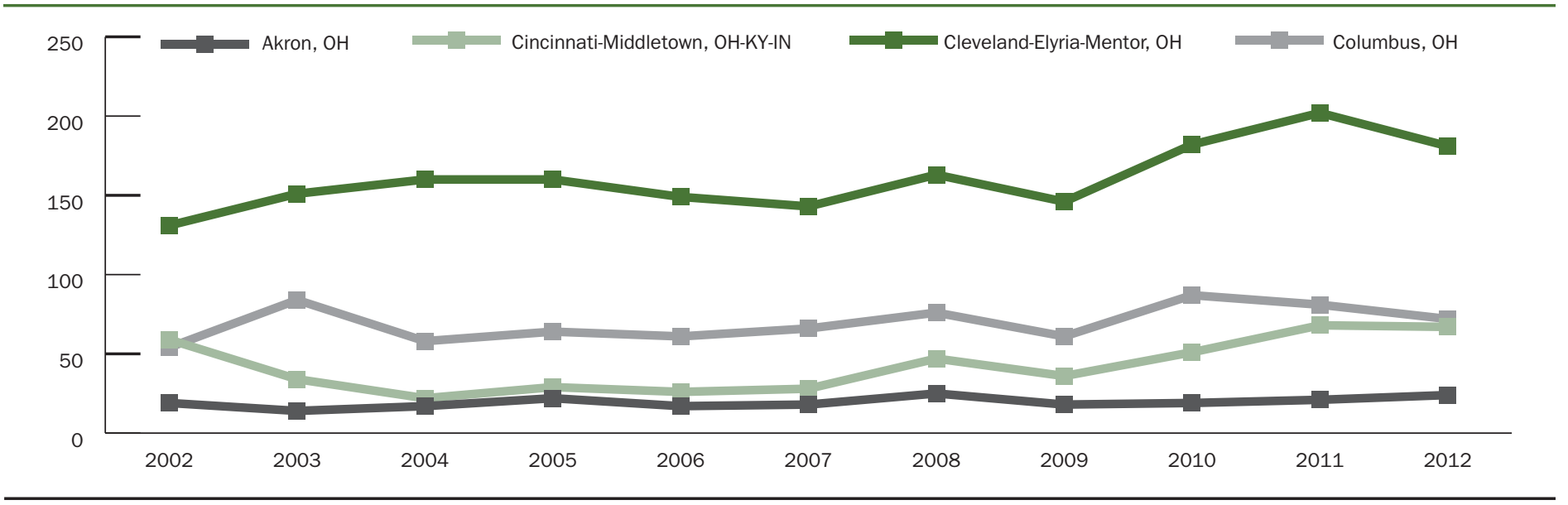

SOURCE: Foundation Center, 2015.

FIGURE 5 Total Dollars Awarded for Economic Development by Metropolitan Area, 2002 to 2012

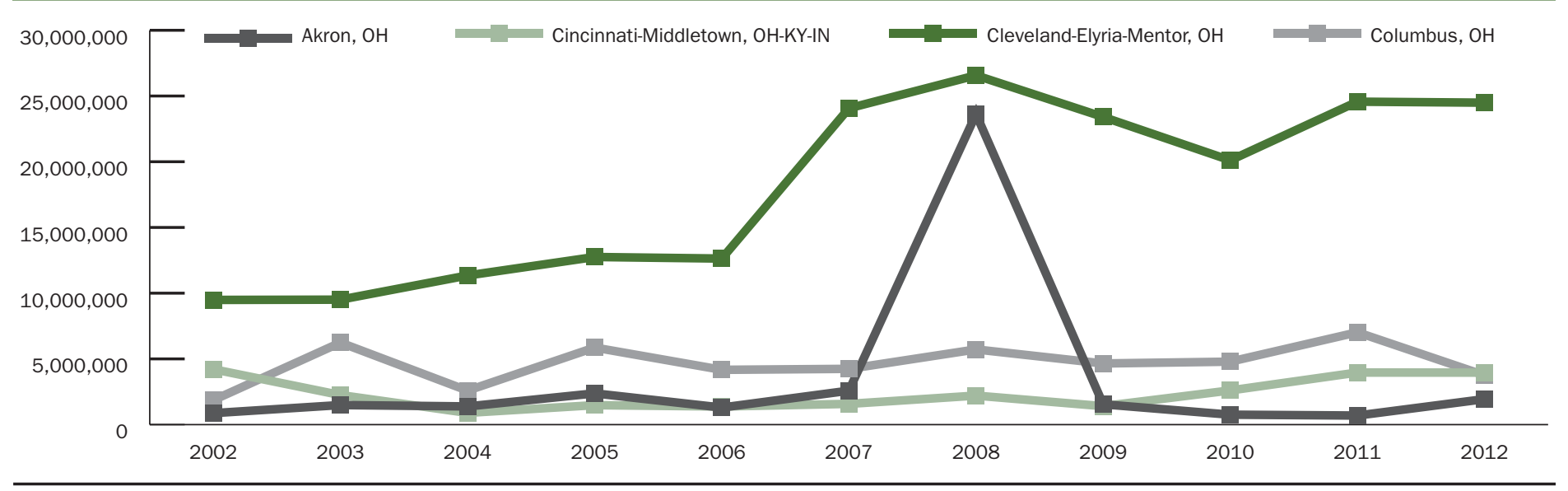

SOURCE: Foundation Center, 2015. 


\section{AWARD SIZES}

There were 48 grants of $\$ 1$ million or more awarded during the period studied, which accounted for 1 percent of the grants awarded but 30 percent of grant dollars (Figure 6). Close to 30 percent of these grants were at the $\$ 1$ million level. By far the highest number of large grants (10) were awarded in 2008 , as well as the single largest grant $-\$ 20$ million from the John S. and James L. Knight Foundation to the University of Akron's Biolnnovation Institute to create the Knight Research and Education Collaborative. Finally, while overall foundation giving surpassed pre-recession levels in 2012, the number of large grants supporting economic development in Ohio has yet to regain its pre-recession peak share. That could be the result of foundation efforts to distribute their funds more broadly throughout the economic development sector through smaller grants.

\section{FIGURE 6 Total Value of Grants of $\$ 1$ Million or More by Year, 2002 to 2012}

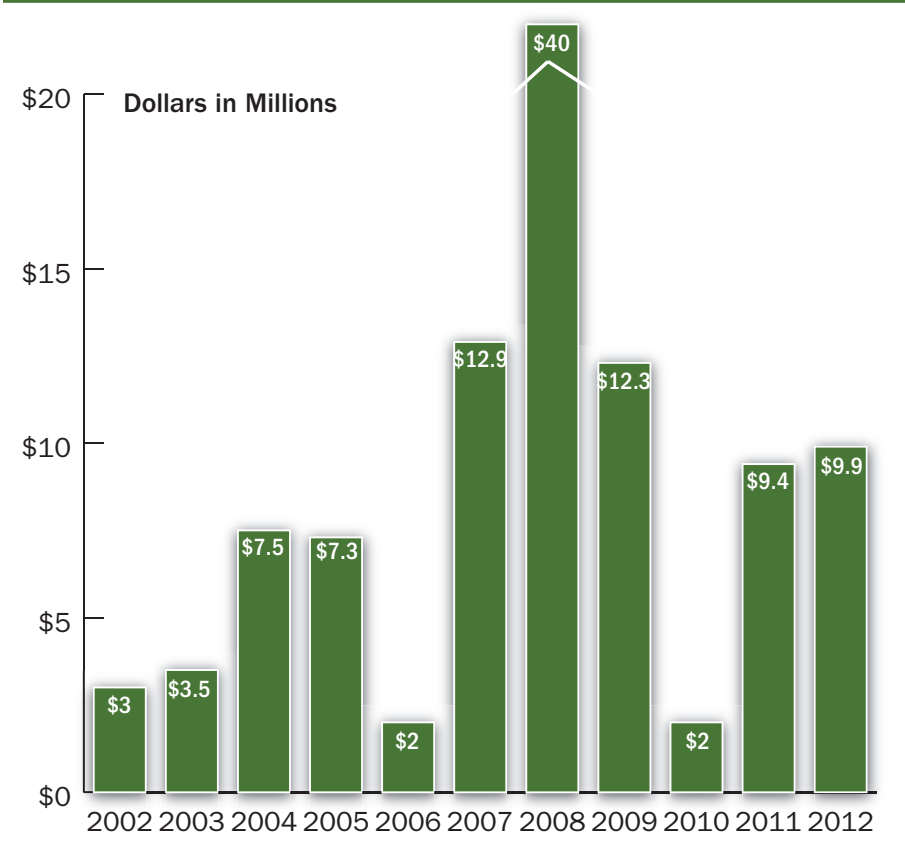

SOURCE: Foundation Center, 2015.
In 2012, Cleveland captured the largest share of grants of $\$ 1$ million or more (64 percent) followed by Columbus, receiving 6 percent of the major grants during the report period.

Conversely, over one-third of gifts (37 percent) were for $\$ 20,000$ or less. These grants totaled $\$ 18,672,778$ or 5 percent of the total dollars awarded for economic development from 2002 to 2012. The majority of grants made for economic development related activities in Ohio between 2002 and 2012 were smaller grant amounts. In 2012, 19 percent of the grants made were for $\$ 10,000$ (Table 4 ).

\section{TELLING THE STORY: PHILANTHROPY \& ECONOMIC DEVELOPMENT}

In this report, Foundation Center has carefully selected core economic development categories to capture trends in philanthropic giving in Ohio over the last decade. Foundation Center's longtime Grants Classification System (taxonomy) created a common language through which researchers could categorize grants and extract data on those grants awarded to nonprofits. This framework allows users to look at grants by recipient type, grant purpose, population served, geography, and support type.

The categories selected for this report reflect primary and secondary grant purposes under general economic development categories including employment/jobs, community improvement/capacity building, and youth development/business. (Foundation Center will be launching a new Philanthropy Classification System in mid-2015, which will continue to enable foundations, researchers, and others to identify grantmaking related to these and other issue areas using a more streamlined and flexible system.)

By its very nature, nonprofit activity evolves over time to meet changing needs in society and consequently, the classification system must allow for flexibility to address these shifting circumstances. Through this report, we hope to spark discussion about how economic development should be defined in the future as foundations and nonprofits endeavor to spur growth and provide opportunities that promote economic prosperity.

—Deborah D. Hoover, President \& CEO of The Burton D. Morgan Foundation

\section{FIGURE 7 Share of Economic Development Grant Dollars by Priority Areas for Ohio, 2002 and 2012}

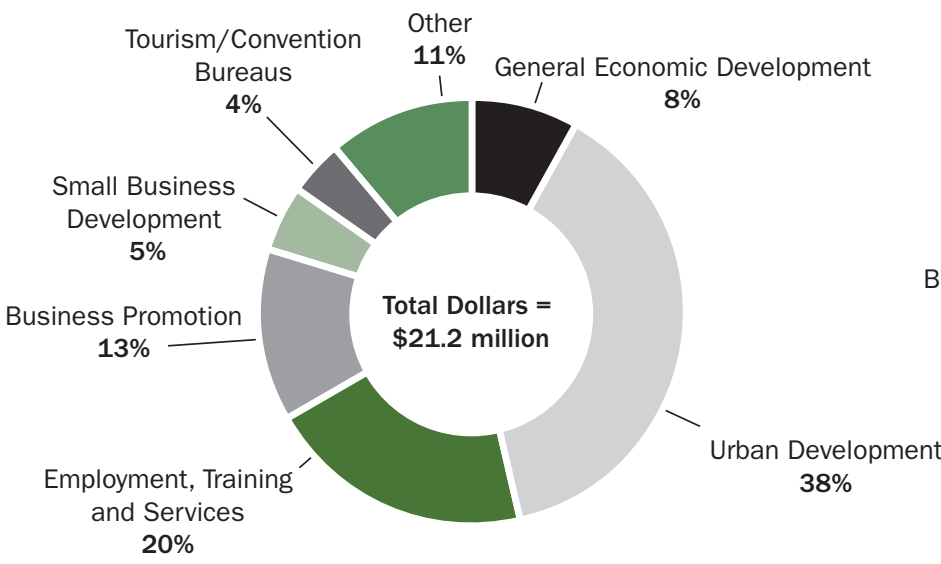

2002

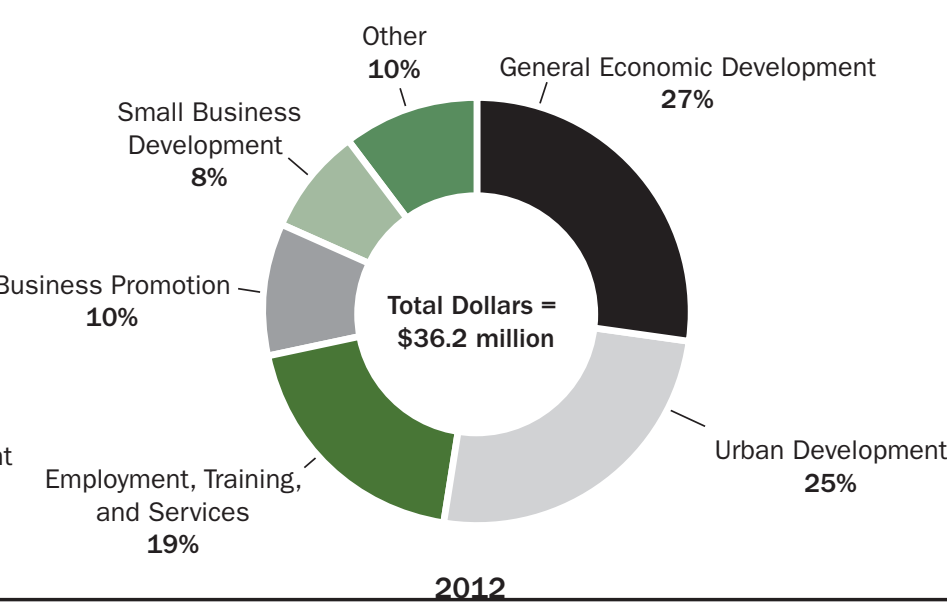

2012

SOURCE: Foundation Center, 2015. Rural Development accounted for 0 percent share of dollars in 2002 and 2012. 
FIGURE 8 Share of Economic Development Grants by Population for Ohio, 2002 to 2012

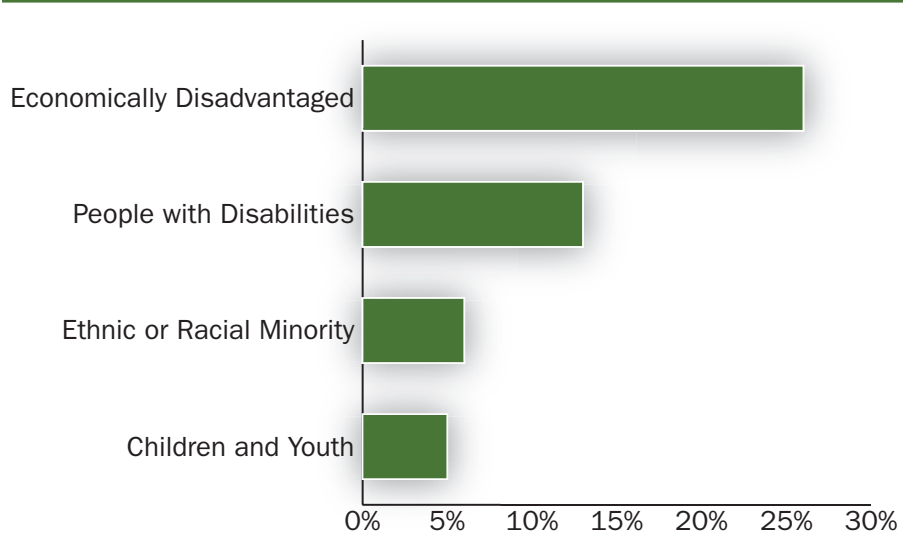

SOURCE: Foundation Center, 2015. Includes selected beneficiary groups representing at least 5 percent of overall grants and represents grants awarded that could be identified as serving specific populations. The chart does not represent all giving benefiting these groups. Grants may benefit more than one population group and could therefore be counted more than once.

FIGURE 9 Share of Economic Development Grant Dollars by Target Population for Ohio, 2002 and 2012

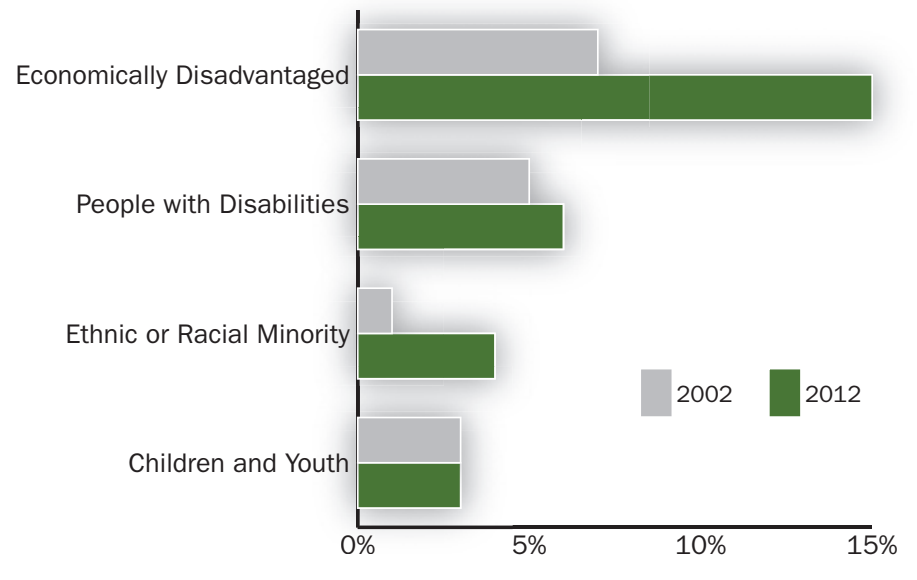

SOURCE: Foundation Center, 2015. Grants may benefit more than one population group and could therefore be counted more than once.
TABLE 4 Economic Development Grants by Grant Size, 2002 to 2012

\begin{tabular}{lcc}
\hline Grants Range & $\begin{array}{c}\text { No. of } \\
\text { Grants }\end{array}$ & $\%$ \\
\hline \$1 Million and over & 48 & 1.3 \\
$\$ 500,000-$ under $\$ 1$ million & 94 & 2.5 \\
$\$ 100,000$-under $\$ 500,000$ & 627 & 16.7 \\
$\$ 50,000-$ under $\$ 100,000$ & 590 & 15.7 \\
$\$ 25,000-$ under $\$ 50,000$ & 933 & 24.9 \\
$\$ 10,000-$ under $\$ 25,000$ & 1,456 & 38.8 \\
Total & 3,748 & 100.0 \\
\hline
\end{tabular}

SOURCE: Foundation Center, 2015. Dollar amount in thousands.

\section{FIGURE 10 Share of Economic Development Grant Dollars by Types of Support for Ohio, 2012}

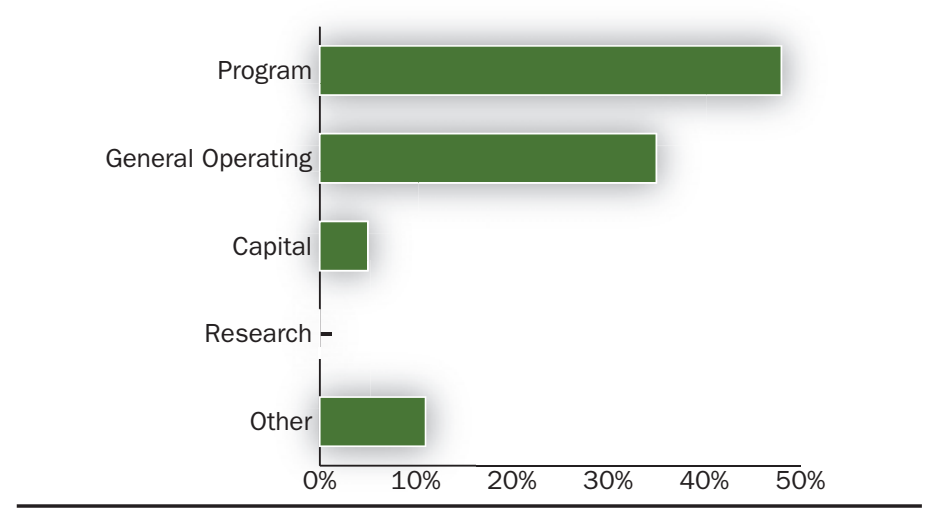

SOURCE: Foundation Center, 2015. Grants may occasionally be for multiple types of support and would therefore be counted more than once.

FIGURE 11 Share of Economic Development Grants by Types of Support for Ohio by Year, 2002 to 2012

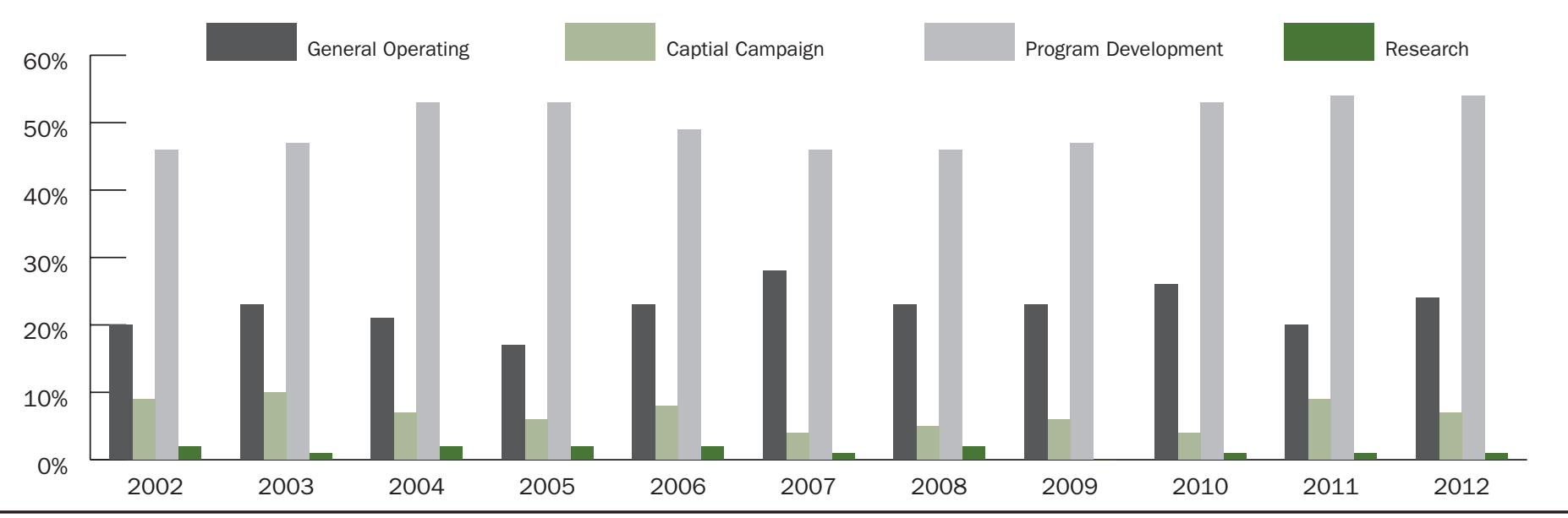

SOURCE: Foundation Center, 2015. Grants may occasionally be for multiple types of support and would therefore be counted more than once. 


\section{GRANTMAKING PRIORITIES}

Between 2002 and 2012, sampled foundations awarded 1,047 grants for employment, training and services, accounting for 28 percent of all grants during that period. One-fifth of grants were for urban development, and a further 14 percent were for general economic development activities. Tourism and rural development received the smallest share of grant dollars in Ohio.

The share of grant dollars awarded to general economic development increased significantly from 2002 (8 percent in 2002 versus

27 percent in 2012) while the share allocated to Urban Development fell from 38 percent in 2002 to 25 percent in 2012 (Figure 7).

\section{TARGET POPULATION}

Among the specified population groups, the economically disadvantaged benefited from the largest share of the number of economic development grants awarded from 2002 through 2012. People with disabilities followed with 13 percent of all Ohio economic development grants.

The share of foundation economic development grant dollars focused on the economically disadvantaged in Ohio more than doubled from 2002 to 2012 . Funding for children and youth remained steady at 3 percent. Overall, 23 percent of grants in the study period were for economically disadvantaged. The Cleveland metro area captured 44 percent of these grants followed by the Cincinnati area with 27 percent.

\section{TYPES OF SUPPORT}

Roughly 50 percent of all grants in Ohio from 2002 through 2012 were for program development (Figure 10). A further 23 percent were for general operating support. Throughout the report period, grants from funders to Ohio nonprofits for economic development activities primarily supported program-related interests. In five of the reporting years, grants made for program support exceeded 50 percent of all grants awarded in those years. And while grants for general operating support increased in 2012 compared to
2002, the shares for general operating support to Ohio recipient organizations has been less than 30 percent (and in most years much less) throughout the 11 year reporting period (Figure 11).

General and operating support is an important type of funding for the sustainability and effectiveness of nonprofit organizations. Of the 23 percent of grants made for general and operating

\section{THE NEXT STAGE OF RESEARCH}

Ohio has a well-established philanthropic community from which innovative models for structured grantmaking aimed at improving the competitiveness of regional economies have emerged. As a result, Ohio serves as a strong model through which to examine economic development grantmaking. The robust and increasingly strategic economic grantmaking that is reflected in this report is not only occurring in the metropolitan areas of Ohio, but is taking place more broadly at increasing levels across the country.

The context for economic development grantmaking is variable, based on locality and timeframe. As a result, several important questions emerged from this report. For example, do foundations in different regions increase their funding for economic development in response to community initiated activities or are they being proactive in setting the economic development agenda? To what extent do emergent economic conditions dictate economic development grantmaking activities? How can foundations planning to work in the economic development space better understand charitable nuances of grants aimed at "lessening the burdens of government?" What role do the small private and community foundations play in economic development grantmaking? How do philanthropic collaborations among large and small funders enhance shared learning and help all foundations to develop more effective economic development lenses for their grantmaking? And finally, what due diligence criteria do philanthropies employ to make targeted investments in this realm?

Future research will explore the local environment in which this grantmaking is occurring and will deepen our understanding of the full scope and impact this form of grantmaking is having on local and regional economies. With increased emphasis on structured and rational investment practices, the philanthropic sector is seeking to ensure maximum impact and transform the communities in which they operate.

_John Bailey, Ph.D., Director of Foundation Center-Cleveland

\section{TABLE 5 Top 10 Ohio Recipients of Economic Development Grants, 2012}

\begin{tabular}{|c|c|c|c|c|c|}
\hline & Recipient Organization & Dollar Amount & Percent (\%) & Number of Grants & Percent (\%) \\
\hline 1 & Fund for Our Economic Future & $\$ 4,743,333$ & 13.0 & 5 & 1.3 \\
\hline 2 & Neighborhood Progress & $2,387,500$ & 6.5 & 4 & 1.0 \\
\hline 3 & Cleveland Center for Arts and Technology & $2,076,000$ & 5.7 & 6 & 1.6 \\
\hline 4 & Cuyahoga Community College & $1,302,047$ & 3.6 & 1 & 0.3 \\
\hline 5 & Chamber of Commerce Foundation of Greater Cincinnati & $1,188,000$ & 3.2 & 13 & 3.4 \\
\hline 6 & JumpStart & $1,174,525$ & 3.2 & 6 & 1.6 \\
\hline 7 & University Park Alliance & $1,035,000$ & 2.8 & 5 & 1.3 \\
\hline 8 & Lorain County Community College Foundation & $1,000,000$ & 2.7 & 1 & 0.3 \\
\hline 9 & BioEnterprise Corporation & 921,000 & 2.5 & 3 & 0.8 \\
\hline \multirow[t]{3}{*}{10} & Columbus Partnership & 910,000 & 2.5 & 5 & 1.3 \\
\hline & Subtotal & $16,737,405$ & 45.7 & 49 & 12.7 \\
\hline & Total & $\$ 36,584,782$ & 100.0 & 385 & 100.0 \\
\hline
\end{tabular}

SOURCE: Foundation Center, 2015. 
support during the 11 year report period, Cleveland captured the largest share of these grants, receiving 50 percent of general and operating support grants awarded. The second largest share of general and operating support grants was awarded to Columbus with 14 percent, followed closely by Cincinnati with 11 percent.

Yet, Cleveland's share of total grants awarded to the metro area that were for general and operating support was the second lowest of Ohio's metropolitan areas, with 24 percent of all grants made for general and operating support. Columbus received only 16 percent for general and operating support. By contrast, Canton and Youngstown both reported the largest shares of general operating support (42 percent and 41 percent respectively) of the total economic development grants they received.

The overall share of grants awarded for research was small across all years. Canton, Youngstown, and Dayton Metropolitan Areas were not awarded any research grants during the reporting period. Those communities that comprise the remainder of Ohio also did not receive any grant support for research related to economic development programming.

In 2012, the largest share of grant dollars went to fund program support. Of the $\$ 36.2$ million awarded that year, $\$ 17.5$ million went to program-related activities. Program support encompasses funding for the development of programs, conferences and seminars, seed money, and online services.

The single largest grant awarded in 2012 was a $\$ 4,000,000$ grant from the George Gund Foundation to the Fund for Our Economic Future for general operating support.

Grants from funders for economic development activities in Ohio that were designated as 'other' include grants that did not specify the type of support those dollars were for.

\section{COUNTIES IN OHIO METROPOLITAN AREAS}

Akron: Summit and Portage counties

Canton-Massilon: Stark and Carroll counties

Cincinnati: Hamilton, Butler, Warren, and Claremont counties

Columbus: Franklin, Licking, Delaware, Fairfield, Pickaway, Union, Hocking, Perry, Madison, and Marrow counties

Cleveland-Elyria-Mentor: Cuyahoga, Lorain, Lake, Medina, and Geauga counties

Dayton: Montgomery, Greene, Preble, and Miami counties

Toledo: Lucas, Wood, and Fulton counties

Youngstown-Warren-Boardman: Mahoning and Trumbull counties

\section{RECIPIENT ORGANIZATIONS}

In 2012, 192 organizations received support for economic development activities in the state (Table 5). Of the top 10 recipients of grants for economic development activities, seven were located in the Cleveland Metropolitan Area. The remaining three recipients were located in the Columbus, Cincinnati, and Akron metropolitan areas.

Some of the notable grants received by top recipients in 2012 include a \$151,000 award from the Burton D. Morgan Foundation to BioEnterprise Corporation for the Business Development and Entrepreneurial Assistance Program and the Business Associates internship program, the Chamber of Commerce Foundation of Greater Cincinnati received a $\$ 225,000$ award from the Greater Cincinnati Foundation for its Minority Business Accelerator, and the Columbus Partnership received a $\$ 350,000$ from the Columbus Foundation to support its economic growth initiative Columbus 2020.

\section{ENDNOTE}

1. To see the previous two reports go to: foundationcenter.org/ gainknowledge/research/regionaltrends.html.

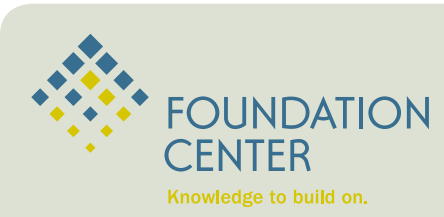

\section{ABOUT FOUNDATION CENTER}

Established in 1956, Foundation Center is the leading source of information about philanthropy worldwide. Through data, analysis, and training, it connects people who want to change the world to the resources they need to succeed. Foundation Center maintains the most comprehensive database on U.S. and, increasingly, global grantmakers and their grants - a robust, accessible knowledge bank for the sector. It also operates research, education, and training programs designed to advance knowledge of philanthropy at every level. Thousands of people visit Foundation Center's website each day and are served in its five library/learning centers and at more than 470 Funding Information Network locations nationwide and around the world. For more information, please visit foundationcenter.org or call (212) 620-4230.
Molly Schnoke is the Project Coordinator with the Center for Community Planning \& Development of the Maxine Goodman Levin College of Urban Affairs at Cleveland State University.

This report was funded in part by:

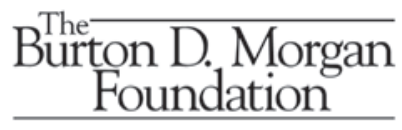

Committed to the Free Enterprise System

\section{The George Gund Foundation}

For more information contact

John Bailey, Director, Foundation Center-Cleveland, at jpb@foundationcenter.org or (216) 861-1933 x321.

Download "Spotlight on Economic Development Grantmaking in Ohio" at: foundationcenter.org/cleveland/economics. 